prevent them from falling off accidentally. Rarely, I observed binoculars tied directly to sticks with strings or rubber bands so that the birder could quickly drop his/her arms to use a scope while leaving the whole binocular-stick complex dangling from the neck. So, why not try making a stick of your own? It's fun to personalize your own functional creation. Especially for people without, or unwilling to carry, heavy scopes and tripods, finnsticks greatly increase your endurance and view in open habitats.

\title{
DIARY OF HOUSE FINCHES IN SOUTHWESTERN SASKATCHEWAN
}

BRENDA AND JOHN FLOOD, Box 475, Leader, SK SON 1 HO e-mail: hiwater@sk.sympatico.ca

We moved to Leader from Calgary in June 1990. The first things out of the moving truck were, of course, our bird feeders.

We were delighted when the first male House Finch arrived at our feeders on April 23, 1995. The bright red male was observed again on April 25. The next time we saw a House Finch was a year later, when a red male visited our feeders each day from April 9 to April 11. On April 22, we observed two male House Finches that were orange variants, clearly different from the one we had seen earlier. We saw the first female House Finch on May 20, and again on May 29 and June 3.

The following year, on April 6, 1997, we again observed a red male House Finch at our feeders and a male and female pair together on April 19. A female was seen again on May 28. In 1998, four red male House Finches visited the feeders on April 3. A female was seen on May 5 and 6 , and a red male on May 7. Our first fall visitors were a red male on October 8, 9, 11 and 12, and a female on October 23.
In 1999, a year with a significant increase in the number at our feeders, House Finches arrived in March and stayed right through the winter. The first arrivals were a red male on March 23 and a female on March 28. April 28 brought an orange variant male. Pairs were feeding each other on April 24 and on May 10. We consistently observed two red males, plus one orange variant, and two females throughout the entire spring and summer months. We surmise that the House Finches nested successfully in the area.

During the fall, from September through October, three females and two red males were observed. At least one pair visited the feeder regularly from November through March, with two males and one female on December 11 and 12 .

The spring of 2000 brought even more House Finches. On April 6, there were two males and one female, and on April 10, three females and four red males. A red male was observed feeding a female on April 30 and May 2, and an adult feeding an immature was noted on 
June 12 (red, adult male) and July 3 (adult female). Throughout June and July, two red and one yellow male as well as two females were regular visitors. The yellow variant male was first seen on June 14. From July 26 to 29 , we had six females (this number could possibly include immatures). An orange variant male was seen on August 9.

Throughout the beginning of August, up to six finches were seen at one time, with young being fed. On August 20, eight House Finches visited the feeders, including five females/immatures, one red adult, two pink immatures and one yellow variant male. On August 27, the number increased to eight females/ immatures and two red, one pink and one yellow male. House Finches were feeding in early September 2000 in mixed flocks with House Sparrows. We watched an immature House Sparrow begging food from an adult female House Finch that moved away and did not feed it.

On September 2, there were fourteen females/immatures plus four bright red males. Over the next few weeks, the female/immature numbers stayed between eight and ten, and the males, up to eight: four bright red, two pink, one yellow and one orange. Six to eight House Finches visited our feeders until the end of October.

On November 5 , the weather turned cold and snow began to blow around 2:00 a.m., continuing through much of the day. Along with a variety of birds at the feeders, we had seven female House Finches, and seven red/pink, one orange and one yellow male. The same numbers were here again on November 6 . The House Finches were very aggressive towards the $200+$ House Sparrows that push their way to the feeders.

The different color variants at our feeders is certainly a nice change from the huge flocks of House Sparrows that are attracted to our feeding stations. We are pleased that the House Finches seem to have nested successfully here. We had from four to fourteen House Finches visiting the feeders right through to the end of March 2001. With the arrival of spring, their wonderful song is a delight through the open kitchen window. It will be interesting to see if the numbers continue to grow throughout the summer.

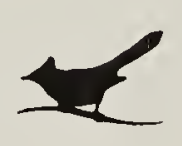

\section{OBSERVATIONS FROM BANDING HOUSE FINCHES IN THE FALL OF 1995 AT REGINA, SK}

DALE AND PAULE HJERTAAS, 15 OIson Place, Regina, SK S4S 2J6.

The House Finch is native to western North America, where it occupies habitats from open desert to urban areas in southern British Columbia east to
Montana and south to southern Mexico. In 1940, a small group of House Finches taken to Long Island, New York for the cage bird trade, were released locally. 